\title{
Intraradicular rehabilitation of a necrotic immature permanent maxillary incisor
}

\author{
Arya Unni, ${ }^{1}$ Arun Mayya $\left(10,{ }^{2}\right.$ Shruti Bhandary, ${ }^{1}$ Anoop Mayya ${ }^{3}{ }^{3}$
}

\section{${ }^{1}$ AJ Institute of Dental Sciences, Mangalore, India \\ ${ }^{2}$ Srinivas Institute of Dental Sciences, Mangalore, India ${ }^{3}$ Melaka Manipal Medical College, Bukit Baru, Melaka, Malaysia}

Correspondence to Dr Anoop Mayya; anoopmayya@gmail.com

Accepted 29 June 2021

\section{DESCRIPTION}

The insufficiency of sound coronal and radicular tooth structure in traumatised immature necrotic teeth commonly poses restorative problems in clinical practice. Pulpal pathology, traumatic injuries of immature teeth, iatrogenic or endodontic mishaps can give rise to flared canals which eventually lead to restorative problems. ${ }^{1}$ Damaged teeth with extensive loss of dentinal tissues can recently be salvaged by reconstitution and rehabilitation using materials with the ability to bond to the dentinal structures. Rebuilding a weakened root with an appropriate adhesive material can provide dimensional and structural reinforcement for supporting and retaining a post and core for sustained function of the tooth. ${ }^{2}$ The presence of a blunderbuss canal can complicate the maintenance of an apical barrier with a three-dimensional seal. ${ }^{3}$ Light-cured or dualcured composite resins, glass ionomers, fibre strips, accessory fibre posts and unpolymerised glass fibre posts can be used for successful management of weakened roots by reinforcement of the remaining root structure. ${ }^{4} \mathrm{~A}$ modified apexification procedure is a recent treatment strategy which can be used in similar cases of immature permanent teeth with pulp necrosis or apical periodontitis requiring a post for a final restoration. This approach has been shown to improve the potential for continued apical root development. ${ }^{5}$ This case demonstrates the intraradicular rehabilitation of an immature necrotic tooth with insufficient coronal tooth structure and subsequent restoration.

A 22-year-old female patient reported with a chief complaint of a broken upper front tooth. The patient gave a history of trauma to the upper front tooth region 13 years ago. Clinical examination revealed a deep proximal caries in relation to tooth \#21 (figure 1A). There were no soft tissue abnormalities detected intraorally. Extraoral examination revealed no abnormalities. Radiographical examination revealed a proximal radiolucency involving the pulp with thin dentinal walls and an open apex (figure 1B). The tooth elicited negative response to thermal and electric pulp testing. Based on the clinical and radiographical findings, a diagnosis of pulp necrosis with asymptomatic apical periodontitis was made. The treatment plan included apexification with mineral trioxide aggregate and reinforcement of the dentinal walls with flowable composite followed by postendodontic restoration using a post and core.

In the first visit, the tooth was anaesthetised using 2\% lignocaine and 1:100000 epinephrine (Dentsply Sirona, York, Pennsylvania, USA) by



Figure 1 (A) Preoperative photograph. (B) Preoperative radiograph. (C) Mineral Trioxide Aggregate (MTA) apexification. (D) Canal reinforcement with composite. (E) Postcementation.

the infiltration technique. Rubber dam isolation was carried out, and access cavity preparation was done under magnification loupes $(3.5 \times$, Zumax). Following pulp extirpation, the tooth was negotiated with a \#15 K file (Dentsply Maillefer, Oklahoma, USA). Working length was determined using an apex locator (Root ZX Mini; J. Morita, Kyoto, Japan) and was confirmed with an intraoral periapical radiograph. The biomechanical preparation was carried out using \#80 K file with frequent irrigation using $2.5 \%$ sodium hypochlorite with a side vented needle. This was followed by irrigation with 17\% EDTA and a final rinse with saline. A $\mathrm{Ca}(\mathrm{OH})_{2}$ intracanal medicament was placed after drying the canal with paper points followed by temporisation of the tooth using Cavit (3M ESPE, St. Paul, Minnesota, USA). In the second visit after 2 weeks, under rubber dam isolation, the canal was thoroughly irrigated using $2.5 \%$ sodium hypochlorite followed by saline to wash out any remnants

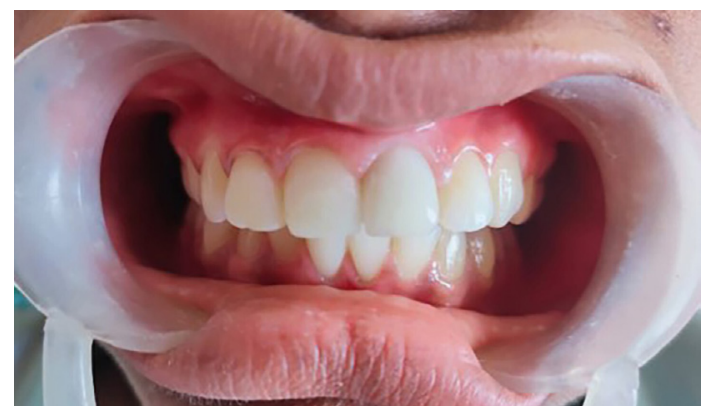

Figure 2 Postoperative photograph. 
of the calcium hydroxide dressing. After drying the canal with suitable paper points, Mineral Trioxide Aggregate (MTA) (MTA Plus, Dentsply Tulsa) apexification was carried out using MTA carrier to create the apical plug. An apical barrier of $4 \mathrm{~mm}$ was established (figure 1C). A finger plugger was used to evaluate the setting of MTA followed by the reinforcement of the canal walls on the same day since the remaining dentin thickness of the walls was less. Etching of the canal was carried out using $37 \%$ phosphoric acid for $15 \mathrm{~s}$; saline irrigation was carried out and dried with paper points. A micro applicator tip was used to apply a thin coating of dentin bonding agent and it was then light cured. A flowable composite resin, G-aenial Universal Flo (GC, India), was injected into the canal and a light transmitting post, Luminex (Dentatus, Weissman Technology), was inserted centrally.

Excess material was removed from the access cavity and a light-curing tip was placed at the end of the post for curing the flowable composite. The post was then removed with a rotating and pulling motion (figure 1D). In the space left after post removal, the post was luted with an adhesive resin cement (Maxcem Elite Kerr Self-cure; Kerr, Orange, California, USA)

\section{Learning points}

- Necrotic immature teeth with less than $2 \mathrm{~mm}$ of remaining root dentin thickness can be rehabilitated before restoration with a post and core.

- The intraradicular reinforcement method involves placing an intermediate layer of adhesive material of suitable thickness, sandwiched between the root dentine and the post, to enhance the fracture resistance of such roots. (figure 1E). The core build-up was done with a core buildup material (LuxaCore Z; DMG, Hamburg, Germany) followed by tooth preparation and recording of the impression. An allceramic crown was then cemented in the next visit (figure 2). A 6-month follow-up showed no significant changes and good patient satisfaction.

Contributors AU: conception and design and endodontic treatment and postspace preparation. ArM: conception and design and intraradicular restoration and follow-up of patient. SB: conception and design. AnM: drafting and revision of the article.

Funding The authors have not declared a specific grant for this research from any funding agency in the public, commercial or not-for-profit sectors.

Competing interests None declared.

Patient consent for publication Obtained.

Provenance and peer review Not commissioned; externally peer reviewed.

\section{ORCID iDs}

Arun Mayya http://orcid.org/0000-0002-7230-3479

Anoop Mayya http://orcid.org/0000-0001-6583-4311

\section{REFERENCES}

1 Tait CME, Ricketts DNJ, Higgins AJ. Weakened anterior roots--intraradicular rehabilitation. Br Dent J 2005;198:609-17.

2 Goncalves LAdeA, Vansan LP, Paulino SM, et al. Fracture resistance of weakened roots restored with a transilluminating post and adhesive restorative materials. J Prosthet Dent 2006;96:339-44.

3 Chhabra N, Chhabra A. Intraradicular reinforcement for traumatized immature teeth. J Dent Child 2014;81:33-7.

4 Mattos CMA, Las Casas EB, Dutra IGR, et al. Numerical analysis of the biomechanical behaviour of a weakened root after adhesive reconstruction and post-core rehabilitation. J Dent 2012:40:423-32.

5 Songtrakul K, Azarpajouh T, Malek M, et al. Modified Apexification procedure for immature permanent teeth with a necrotic Pulp/Apical periodontitis: a case series. J Endod 2020;46:116-23.

Copyright 2021 BMJ Publishing Group. All rights reserved. For permission to reuse any of this content visit

https://www.bmj.com/company/products-services/rights-and-licensing/permissions/

BMJ Case Report Fellows may re-use this article for personal use and teaching without any further permission.

Become a Fellow of BMJ Case Reports today and you can:

- Submit as many cases as you like

- Enjoy fast sympathetic peer review and rapid publication of accepted articles

- Access all the published articles

- Re-use any of the published material for personal use and teaching without further permission

Customer Service

If you have any further queries about your subscription, please contact our customer services team on +44 (0) 2071111105 or via email at support@bmj.com.

Visit casereports.bmj.com for more articles like this and to become a Fellow 